\title{
Effect of Arduino Uno Based Microcontroller Media TrainerAgainst Student Learning Outcomes Psychomotor in the Basic Competencies Controlling the Input and Output Ports in Surabaya KAL-1 Vocational School Judging from the Level of Creative Thinking
}

\author{
K S Budi 1 , S Muslim², A B Santosa ${ }^{3}$, D M Putra ${ }^{4}$ \\ \{karnobudi16070895001@mhs.unesa.ac.id ${ }^{1}$, supari@unesa.ac.id ${ }^{2}$, agusbudisantosa@unesa.ac.id ${ }^{3}$, \\ dickyputra16070895009@mhs.unesa.ac.id $\left.{ }^{4}\right\}$ \\ 1,2,3,4 Electrical Engineering Education, Universitas Negeri Surabaya, Indonesia
}

\begin{abstract}
The objectives of the study were: (1) to analyze the differences in learning outcomes between students who studied using Arduino Uno media trainers and students who studied using AVR media trainers at Surabaya KAL-1 Vocational School; (2) analyze the differences in learning outcomes between students who have a high level of creative thinking and students who have a low level of creative thinking at Surabaya KAL-1 Vocational School; (3) analyze the interaction between the use of media trainers and creative thinking on the learning outcomes of students of Surabaya KAL-1 Vocational School. The type of this research is quasy experiment using factorial $2 \times 2$ design, and data is analyzed using two-way Anava. The study found: (1) the average score of psychomotor domain learning outcomes (85.11) for students learning by using Arduino media trainers, significantly higher than the average score of psychomotor domains (74.80) for students learning using AVR media trainer; (2) the average score of psychomotor domains for students who have a high level of creative thinking (91.47), significantly higher than psychomotor domain learning outcomes for students who have a low level of creative thinking (78.09); (3) there is a significant interaction between the application of the media trainer and the level of creative thinking on the learning outcomes of the psychomotor domain.Key words: LED TV learning media, student response, learning outcomes, vocational students.
\end{abstract}

Keywords: Media trainer, student learning outcomes, level of creative thinking, and vocational school

\section{Introduction}

Microcontroller subject matter is very necessary in order to increase students' readiness to work. Because almost all equipment in the industry has used information in the production process. Meanwhile, to better study microcontroller material, a microcontroller trainer media is needed [1]. The general facts show that the microcontroller media trainers in the school have not been able to provide understanding to students about microcontroller material and have not been able to improve students' creative thinking skills. Because the AVR microcontroller trainer 
media used in schools is still relatively complicated, making it difficult for students to understand. In relation to the government's efforts to improve the quality of education in the Secondary Championship (Vocational School), the President of the Republic of Indonesia issued Presidential Instruction No. 9 of 2016 [2]. The instruction of the President of the Republic of Indonesia contains the Revitalization of Vocational High Schools in order to improve the quality and competitiveness of Indonesian human resources, including through contextual learning about material taught by teachers, such as the use of instructional media in the form of trainers that can foster students' creative power [2].

From the background above, this study aims to analyze: (1) learning outcomes for students taught by using Arduino Uno-based microcontroller media trainers and students taught by using AVR microcontroller media trainers on basic competencies controlling input and output ports in KAL Vocational School -1 Surabaya; (2) learning outcomes on basic competencies controlling input and output ports between students who have a high level of creative thinking and students who have a low level of creative thinking at Surabaya KAL-1 Vocational School; (3) the interaction between the use of microcontroller media trainers and creative thinking on learning outcomes in basic competencies controls the input and output ports at Surabaya KAL1 Vocational School. While for the formulation of the problem in this study are as follows: (1) whether the learning outcomes for students taught using Arduino Unobased microcontroller media trainers are higher than learning outcomes for students taught using AVR microcontroller trainer learning media on basic competencies controlling input and output ports in Surabaya KAL-1 SMK ?; (2) are the learning outcomes for students who have a high level of creative thinking, higher than the learning outcomes for students who have a low level of creative thinking on basic competencies controlling the input and output ports in Surabaya KAL-1 Vocational School ?; is there an interaction between the media of learning and creative thinking towards learning outcomes in the basic competencies in controlling input and output ports at Surabaya KAL-1 Vocational School?

\section{Literature review}

\subsection{Arduino Based Microcontroller Trainer Media}

Media trainers are very much needed in the learning process especially during practical lessons [3]. The media trainer referred to here is a teaching aid that can be absorbed by the eyes and ears with the aim of helping the teacher so that the student learning process is more effective and efficient [4]. The microcontroller media trainer used in this study is based on Arduino Uno. Arduino Uno is defined as an open source electronic platform, based on software and hardware that is flexible and easy to use [5]. Thus it can be concluded that the Arduino Uno-based microcontroller based media trainer is an Arduino Uno based microcrocontroller that can help improve the ability of the level of creative thinking and psychomotor domain learning outcomes. The Arduino Uno media trainer is shown in figure 1 below. 


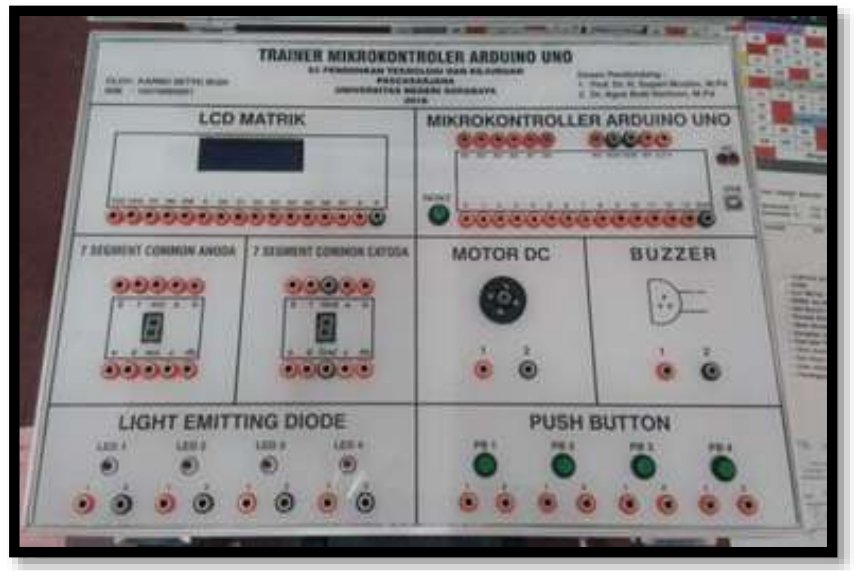

Figure 1. Arduino Uno Media Trainer (Source: Data researcher, 2018)

\subsection{Student's Creative Thinking Ability}

According to Suparji [6], the use of Arduino microcontroller trainers can improve students' ability to think creatively with fluency, flexibility, and novelty. The level of creative thinking is also interpreted as a mental activity that is used by someone to develop new ideas or ideas fluently, flexibility, and novelty [7]. By using media trainers students will try to do their experiments by working according to the plan, and making the results of their work become something better, more meaningful, and more beautiful [8]. Thus it can be stated that with the use of Arduino Uno microcontroller media trainers can improve the ability of the level of creative thinking for students and be able to give birth to something new, both in the form of ideas and works that are relatively different from before, so as to improve psychomotor domains of learning outcomes.

\subsection{Learning Outcomes of the Psychomotor domain}

In addition, it can improve the ability of the level of creative thinking, that the use of Arduino Uno media trainers can also affect the learning outcomes of the psychomotor domain. Learning outcomes can be explained by understanding the two words that make it up, namely results and learning. Understanding the results refers to an acquisition due to an activity or process that results in changes in input functionally. While learning is an activity carried out by students to understand a material [9].

According to Basuki [10] psychomotor domain learning outcomes (the psychomotor domain) is an acquisition of results related to aspects of skills that involve the functioning of the nervous system and muscles (neuromuscular system) and psychological functions. Supporting the above theory, Muslims [11] state that psychomotor domain learning outcomes can be assessed from two references, namely reference procedures and reference results. Assessment of learning outcomes in the psychomotor domain with a procedure is an assessment of students' abilities in terms of: (1) preparing a detailed plan for a project; (2) determine the amount of material 
needed; (3) choosing the appropriate tools; (4) follow the correct procedures for each implementation; (5) using tools properly and skillfully; (6) use unnecessary scattering materials; and (7) perfecting work in a timely manner. Psychomotor domain competency assessment of students with reference to results is an assessment of the quality of student work which includes: (1) whether the product is good and perfect; (2) whether the distribution is in accordance with the original plan; (3) whether the final result matches the specifications; and (4) whether the circuits are going well.

From the opinion of some experts above, it can be concluded that psychomotor domain learning outcomes are the acquisition of student learning processes and the occurrence of changes in student behavior due to learning in accordance with learning objectives, while psychomotor domains learning outcomes are assessed by reference procedures and reference results.

\subsection{Basic Competence Controlling Port Inputs and Outputs}

The basic competencies used in this study are controlling input and output ports. Controlling or controlling is an activity carried out by a microcontroller media trainer to control output components such as LED, Seven Segmant, LCD, DC Motor, and Buzzer according to the program language that has been made [12]. Inside the microcontroller consists of a CPU, ROM, RWM, parallel I / O, series I / O, countertimer, and clock circuits on one single chip. The microcontroller was first introduced by Texas Instruments with the TMS 1000 series in 1974 which was the first 4 bit microcontroller [13]. The microcontroller diagram block is shown in figure 2 below.

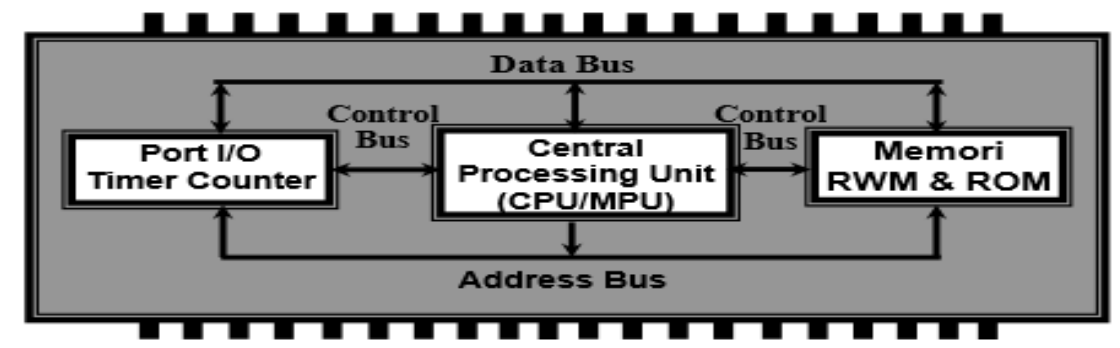

Figure 2. Microcontroller diagram (source: [14])

As shown in Figure 2, that the microcontroller diagram consists of several parts, namely: (1) I / O port that serves to provide input from the input port and provide output commands from the output port; (2) CPU that functions to process programs from inputs that will be executed in output; and (3) Memory that functions to store program memory permanently or temporarily [12]. In the classroom learning process about basic competencies controlling input and output ports, it is very necessary to have teaching aids to simulate learning activities. In addition students must master the material to control input and output ports, but students must also be able to test the actual tools.

The props used in this study are Arduino Uno based microcontrollers. Arduino Uno is an open-source electronic prototype system that is flexible and easy to use both from the hardware and software side. In addition, the superiority of Arduino Uno is that there are a large number of users, so there are a large number of program code and supporting modules. This makes it easier for students to get to know the world of microcontrollers better [15]. 
The advantages of Arduino Uno compared to other microcontroller hardware platforms include: (1) Arduino IDEs are multiplatform, which can be run on various operating systems, such as Windows, Macintosh and Linux; (2) The Arduino IDE is based on a simple Processing IDE so that it is easy to use; (3) Arduino programming uses a cable connected to a USB port instead of a serial port. This feature is useful because many computers today do not have serial ports; (4) Arduino is open source hardware and software, so readers can download Arduino software and images without having to pay to the Arduino maker [16]. The shape of the Arduino board looks like Figure 3 below.

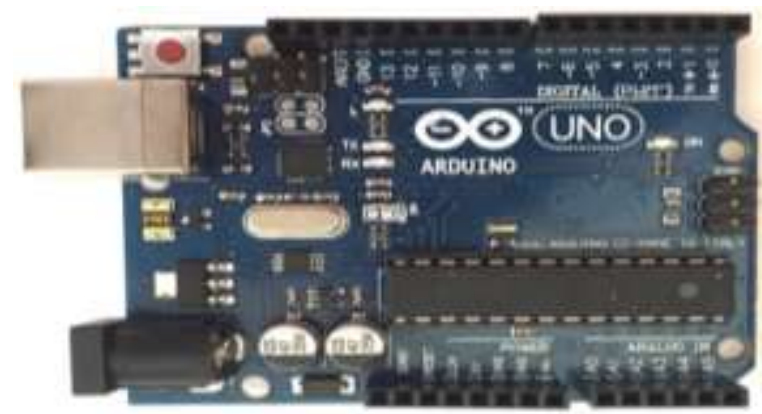

Figure 3. Arduino Uno Board (Source: [12])

Based on Figure 3, the Arduino Uno Board has 6 Analog Inputs, 13 Digital Inputs, 5 Volt DC Arduino Uno source voltage, and USB downlouder that has become one with the Arduino Uno board. Arduino Uno based media trainer microcontroller is very suitable to be applied to the basic competencies in controlling input and port output in class X Audio Video Engineering in Competence of Audio Video Engineering Skills in Vocational Schools [16].

\section{Method}

This study included a type of quasy experimental study using a factorial design. Factorial design uses two groups, namely: (1) the experimental group is students of class X TAV A who study using the Arduino Uno media trainer; and (2) the control group is class X TAV B students who learn using the AVR media trainer, with moderator variables on the level of students' creative thinking [17]. The research design as shown in Table 1 is as follows.

Table 1. Research Design

\begin{tabular}{|cccc|}
\hline \multirow{2}{*}{ Learning Outcomes of Students } & \multicolumn{2}{c|}{ Creative Thinking } \\
& & Low $\left(\mathrm{Y}_{\mathbf{1}}\right)$ & High $\left(\mathrm{Y}_{\mathbf{2}}\right)$ \\
\hline \multirow{2}{*}{ Media Trainer } & Arduino Uno $\left(\mathrm{X}_{1}\right)$ & $\mathrm{X}_{1} \mathrm{Y}_{1}$ & $\mathrm{X}_{1} \mathrm{Y}_{2}$ \\
& $\mathrm{AVR}\left(\mathrm{X}_{2}\right)$ & $\mathrm{X}_{2} \mathrm{Y}_{1}$ & $\mathrm{X}_{2} \mathrm{Y}_{2}$ \\
\hline
\end{tabular}

Information :

X1 Y1 = Learning outcomes of students who learn using the Arduino Uno media trainer, with levels low creative thinking.

X2 Y1 = Learning outcomes of students who study using the AVR media trainer, with a level of thinking low creative. 
X1 Y2 = Learning outcomes of students who study using the Arduino Uno media trainer, with levels high creative thinking

X2 Y2 = Learning outcomes of students who study using the AVR media trainer, with a level of thinking creative high

Data collection techniques used in this study, are through: (1) observation; (2) tests of cognitive learning outcomes; (3) observation of affective, psychomotor domains of learning outcomes; (4) test students' level of creative thinking. The instruments used in this study were: (1) media trainer validation sheets, (2) learning device validation sheets, (3) tests of students' creative thinking ability levels, and (4) validation sheets for observation of affective and psychomotor learning outcomes. The instrument test conducted at SMK PGRI 4 Surabaya was to find out: (1) the validity of the item; (2) the level of difficulty of the item; (3) different power indices; (4) distractor analysis; and (5) reliability of affective and psychomotor learning outcomes observation sheets. The data analysis technique used is two-way Anava with the help of SPSS, by applying the prerequisite test, namely the nomination test and homogeneity test.

\section{Result and Discussion}

This study included a type of quasy experimental study using a factorial design. Factorial design uses two groups, namely: (1) the experimental group is students of class X TAV A who study using the Arduino Uno media trainer; and (2) the control group is class X TAV B students who learn using the AVR media trainer, with moderator variables on the level of students' creative thinking [17]. The research design as shown in Table 1 is as follows.

\begin{tabular}{|cccc|}
\hline \multirow{2}{*}{ Learning Outcomes of Students } & \multicolumn{2}{c|}{ Creative Thinking } \\
& & Low $\left(\mathbf{Y}_{\mathbf{1}}\right)$ & High $\left(\mathbf{Y}_{\mathbf{2}}\right)$ \\
\hline \multirow{2}{*}{ Media Trainer } & Arduino Uno $\left(\mathrm{X}_{1}\right)$ & $\mathrm{X}_{1} \mathrm{Y}_{1}$ & $\mathrm{X}_{1} \mathrm{Y}_{2}$ \\
& AVR $\left(\mathrm{X}_{2}\right)$ & $\mathrm{X}_{2} \mathrm{Y}_{1}$ & $\mathrm{X}_{2} \mathrm{Y}_{2}$ \\
\hline
\end{tabular}

Information :

Table 1. Research Design

X1 Y1 = Learning outcomes of students who learn using the Arduino Uno media trainer, with levels low creative thinking.

$\mathrm{X} 2 \mathrm{Y} 1$ = Learning outcomes of students who study using the AVR media trainer, with a level of thinking low creative.

X1 Y2 = Learning outcomes of students who study using the Arduino Uno media trainer, with levels high creative thinking

X2 Y2 = Learning outcomes of students who study using the AVR media trainer, with a level of thinking creative high

Data collection techniques used in this study, are through: (1) observation; (2) tests of cognitive learning outcomes; (3) observation of affective, psychomotor domains of learning outcomes; (4) test students' level of creative thinking. The instruments used in this study were: (1) media trainer validation sheets, (2) learning device validation sheets, (3) tests of students' creative thinking ability levels, and (4) validation sheets for observation of affective and psychomotor learning outcomes. The instrument test conducted at SMK PGRI 4 Surabaya was 
to find out: (1) the validity of the item; (2) the level of difficulty of the item; (3) different power indices; (4) distractor analysis; and (5) reliability of affective and psychomotor learning outcomes observation sheets. The data analysis technique used is two-way Anava with the help of SPSS, by applying the prerequisite test, namely the nomination test and homogeneity test.

In this section a discussion is conducted to compare the results of the research with the theories and the results of relevant studies. As stated above, psychomotor domain learning outcomes for students learning using Arduino Uno media trainers are significantly higher than psychomotor learning outcomes of students learning using AVR media trainers on basic competencies controlling the input and output ports in KAL Vocational School. 1 Surabaya. Students' psychomotor learning outcomes are changes in student behavior due to the learning process that has been done [18], and according to Muslims [11] that the psychomotor domains of learning outcomes consist of five ratings, namely rankings of imitation, manipulation, precision, articulation and naturalization. The results of the research on the application of Arduino Uno media trainers in this study are in line with the results of Budiarso's research [19] who found that the use of Arduino Uno media trainers can help students learn software and electronics programming in the Arduino Uno I/O interface so as to obtain psychomotor domains students according to learning objectives. Thus it can be concluded that the Arduino Uno media trainer is an intermediary media device for conveying subject matter "controlling input and output ports" to students so that the students' psychomotor learning outcomes match the learning objectives made by the teacher. The results of this study are in accordance with the study of theory which states that the use of media trainers can improve psychomotor domain learning outcomes for students [1]. The results of this study are also in accordance with the results of Shaikh's research [20] that by using the Arduino Uno tool, teachers are easier to transfer knowledge to students, because students can directly apply the theory obtained in practical learning activities.

Psychomotor domains for students who have a high level of creative thinking, are higher than psychomotor domains for students who have a low level of creative thinking on basic competencies controlling the input and output ports at KAL 1 Surabaya Vocational High School. The results of this study indicate that to improve the psychomotor domain of learning outcomes, the level of creative thinking skills for students needs to be improved. While creative thinking is a thought process that has indicators of fluency, flexibility, and novelty [7]. The results of this study are supported by what was stated by Suparji [6] that students 'creative thinking skills can support students in understanding the lesson, because these students will try to experiment independently and get experiences that cannot be forgotten so that the students' psychomotor learning outcomes can increase. The results of this study support the results of the study of Reilly [18] who found that learning outcomes for students who had a high level of creative thinking were significantly higher than students who had a low level of creative thinking. The level of creative thinking of students is very influential on psychomotor domain learning outcomes [7]. The results of this study also support the results of Suparji's research [6] that students who have a high level of creative thinking, obtain higher psychomotor domain learning outcomes than students who have a low level of creative thinking.

There is an interaction between the use of Arduino Uno media trainers, the use of AVR media and the level of students' creative thinking towards psychomotor domain learning outcomes in basic competencies controlling the input and output ports at KAL 1 Surabaya Vocational High School. Interaction is the effect of experimental treatment on the dependent variable that is scored at each level of the moderator variable [23]. Kerlinger [19] states that 
interaction is the effect of an independent variable on a dependent variable, depending on the level or level of other independent variables. If students have a high level of creative thinking, and in learning using the Arduino Uno media trainer, it will provide opportunities for students to think creatively so they will be able to improve their learning outcomes. Psychomotor realm learning outcomes for students who have a high level of creative thinking who learn by using Arduino Uno media trainers, obtain high psychomotor domain learning outcomes, and for students who have a low level of creative thinking who learn using AVR trainers to obtain psychomotor domains high. This gives a clue, that there is an interaction between the use of media trainers, and creative thinking on the learning outcomes of the psychomotor domain. Thus, the Arduino Uno Media trainer is very suitable to be used for learning for students who have a high level of creative thinking [21], because media trainers have more input and output so that to do experiments, students need to think more creatively, and for students who have a low level of creative thinking, more suitable to learn by using the AVR media trainer, because AVR media trainers have a simple design equipped with fewer input and output, so that when students operate the AVR media trainer, it does not require a high level of creative thinking. However learning media has an important influence on student learning outcomes, because it is able to facilitate interaction between teachers and students, so that learning activities will be more effective and efficient [22], especially the use of e-learning media, which have properties that can be utilized whenever and wherever students are in. As one example of E-learning as a learning medium in building techniques has advantages, because it can be accessed anytime and anywhere, student assignments and teaching materials can be accessed easily efficiently, and can support communication and discussion activities between students and instructors [23].

\section{Conclusion}

Based on the results of the research and discussion as described above, it can be concluded that: (1) the average score of psychomotor domains (85.11) for students who study using the Arduino media trainer is significantly higher than the average score of learning outcomes psychomotor domain (74.80) for students who learn by using AVR media trainers on basic competencies to control input and output ports at Surabaya KAL-1 Vocational School; (2) the average score of psychomotor domains for students who have a high level of creative thinking (84.78), is significantly higher than psychomotor domains for students who have a low level of creative thinking (82.67) in basic competencies control input and output ports; (3) there is a significant interaction between the application of media trainers and the level of creative thinking on psychomotor domain learning outcomes in basic competencies controlling the input and output ports at Surabaya KAL-1 Vocational School.

\section{References}

[1] Afandi, "Pengembangan media trainer arduino uno pada mata pelajaran teknik mikroprosesor di SMKN 2 Surabaya," J. Pendidik. Tek. Elektro, vol. 5, no. 3, pp. 747 $-752,2016$.

[2] Presiden Republik Indonesia, Undang-Undang Nomor 9 Tahun 2016 tentang Revitalisasi sekolah menengah kejuruan dalam rangka peningkatan kualitas dan daya saing sumber daya manusia Indonesia. Jakarta, 2016.

[3] P. Agustina, Psikologi perkembangan. Surakarta: PGSD UMS, 2011.

[4] N. Sudjana, Cara belajar siswa aktif dalam proses belajar mengajar. Bandung: Sinar 
Baru Algesindo, 2002.

[5] Artanto, Aplikasi mikrokontroler atmega8535 dan atmegal6. Yogyakarta: Andi publisher, 2012.

[6] Suparji, "Creative thinking level of student in measuring situation map area through multiple solution tasks(case study on nganjuk state-1 vocational high school)," $J$. Basic Appl. Sci. Res., vol. 7, pp. 28-33, 2017.

[7] L. Nurlaela and E. Ismayati, Strategi Belajar Berpikir Kreatif. Yogyakarta: Ombak, 2015.

[8] A. J. Starko, Creativity in the classroom. London: Taylor \& Francis e-Library, 2010.

[9] Purwanto, Evaluasi hasil belajar. Yogyakarta: Pustaka Belajar, 2011.

[10] I. Basuki and Hariyanto, Assesmen pembelajaran. Bandung: PT. Remaja Rosdakarya Offset, 2014.

[11] M. Supari, Kisi-kisi lembar pengamatan hasil belajar. Surabaya: Unipres Unesa, 2013.

[12] M. Syahwil, Panduan mudah simulasi dan praktek mikrokontroler arduino. Yogyakarta: Andi publisher, 2013.

[13] A. Kadir, Panduan praktis mempelajari aplikasi mikrokontroler dan pemrogramannya menggunakan arduino. Yogyakarta: Andi, 2012.

[14] Sumardi, Mikrokontroller belajar avr mulai dari nol. Yogyakarta: Graha Ilmu, 2013.

[15] P. Reguera, D. García, M. Domínguez, M. A. Prada, and S. Alonso, "A LOW-COST OPEN SOURCE HARDWARE IN CONTROL EDUCATION. CASE STUDY: ARDUINO-FEEDBACK MS-150," IFAC-PapersOnLine, vol. 48, no. 29, pp. 117$122,2015$.

[16] Firmansyah, "Pengembangan trainer mikrokontroler berbasis arduino uno sebagai media pembelajaran pada mata pelajaran teknik mikroprosesor di kelas X TEI SMK Negeri 1 Bangil Kabupaten Pasuruan,” J. Pendidik. Tek. Elektro, vol. 6, no. 2, pp. 155 - 160, 2017.

[17] Sugiyono, Metode penelitian pendidikan kuantitatif, kualitatif dan $R \& D$. Bandung: Alfabeta, 2013.

[18] C. J. O’Reilly, “Creative Engineers: Is Abductive Reasoning Encouraged enough in Degree Project Work?,” Procedia CIRP, vol. 50, pp. 547-552, 2016.

[19] F. N. Kerlinger, Fundations of behavioral research: educational and psychological enquiry. New York: Rinehart and Winsto. Inc., 1972.

[20] Z. Budiarso, E. Winarno, and H. Listiyono, "Implementasi teknik I/O interfacing berbasis arduino," Dinamik, vol. 20, no. 1, pp. 86-92, 2015.

[21] Rubio, M. A., C. M. Hierro, and A. P. D. M. Pablo, "Using arduino to enhance computer programming course in science and engineering," in Proceeding of Edulearn 13 Conference, 2013.

[22] S. Muslim, B. Suprianto, and N. Putra Gitama, "Development Module (Lab Report) As a Media of Learning in Vocational Education Viewed by Gender," IOP Conf. Ser. Mater. Sci. Eng., vol. 336, p. 12035, Apr. 2018.

[23] Soeparno and S. Muslim, "Effectiveness of E-Learning for Students Vocational High School Building Engineering Program," IOP Conf. Ser. Mater. Sci. Eng., vol. 336, p. 12039, Apr. 2018. 